\title{
First record of Aspidoscelis motaguae (Sackett, 1941) (Reptilia: Squamata: Teiidae) from Nicaragua
}

\author{
Gunther Köhler ${ }^{1 *}$, Milton Salazar Saavedra ${ }^{2}$, Jose Martinez ${ }^{2}$, Gabriel Lopez ${ }^{3}$ and Javier Sunyer ${ }^{2}$ \\ 1 Senckenberg Forschungsinstitut und Naturmuseum, Senckenberganlage 25, 60325 Frankfurt a.M., Germany. \\ 2 Universidad Nacional Autónoma de Nicaragua (UNAN-León), León, Nicaragua. \\ 3 Parque Nacional Volcan Masaya, Km 22 carretera Managua-Masaya, Nicaragua. \\ * Correspondending author. E-mail: gkoehler@senckenberg.de
}

\begin{abstract}
Reporting on the first locality in Nicaragua, we extend the known geographic distribution of Aspidoscelis motaguae (Sackett, 1941) about $43 \mathrm{~km}$ southeastward from its nearest known locality, in Honduras. We shortly discuss some conservational implications and provide a photo of one Nicaraguan individual that was not collected.
\end{abstract}

Aspidoscelis motaguae (Sackett, 1941) is a mediumsized teiid lizard that is distributed disjunctly from Oaxaca, Mexico, across eastern Guatemala and northwestern El Salvador to Honduras, Central America (Duellman and Wellman 1960; Meyer and Wilson 1973; Köhler 2008).

On 27 April 2012, five individuals of Aspidoscelis motaguae were observed in an area of proximately 10 $\mathrm{m}^{2}$ about $600 \mathrm{~m}$ southeast of the small village Las Minas (13²5'13.17"N, 8644'15.91"W; WGS84), ca. $680 \mathrm{~m}$ elevation, Santa María municipality, Departamento Nueva Segovia, Nicaragua, none of which were preserved (Figure 1). A sixth individual of this species found dead at the same site was collected. Eyes and tympanum had been eaten by ants but otherwise the specimen appeared to be in good condition. It was deposited in the collection of Senckenberg Research Institute (SMF), Frankfurt, Germany, and catalogued under the voucher number SMF 94170. This represents the first record in Nicaragua and extends the known geographic distribution of $A$. motaguae about 43 $\mathrm{km}$ southeastward from its nearest published locality in El Zamorano, Departamento Francisco Morazán, Honduras (Meyer and Wilson 1973). The collected individual is an adult female (snout-vent length $116 \mathrm{~mm}$, tail length 219 $\mathrm{mm}$ ). In external morphology it agrees well with the descriptions and illustrations provided in Duellman and Wellman (1960) and Köhler (2008).

The habitat at the collection site is pine-oak forest corresponding to Tropical Dry Forest formation of Holdridge (1967) in succession Stage 1. The current vegetation consists mostly of vines (Combretum sp., Cydista sp.), shrubs (Acacia collinsi, Byrsonima crassifolia, Lonchocarpus sp.), herbs (Mimosa sp., Paspalum sp., Sida sp.), and scattered trees (Diospiros salicifolia, Enterolobium cyclocarpum, Guarea sp., Guazuma ulmifolia, Lisiloma sp., Sapindus saponaria, Schoepfia screbberi, Tabebuhia rosae var. neochrysanta, Trichilia sp.).

This range extension might seem to be of little importance at first sight because it is just a few kilometres away from the nearest known locality in Honduras. However, the formal addition of a species to a country's faunal list by itself has some conservational implications.
First, it is important to document the distributional endpoints of species as closely as possible, especially given the rapid destruction of all natural habitats in Central America. Second, having documented a species to occur in a certain country might trigger conservation action or at least awareness from governmental and nongovernmental institutions in the respective country.

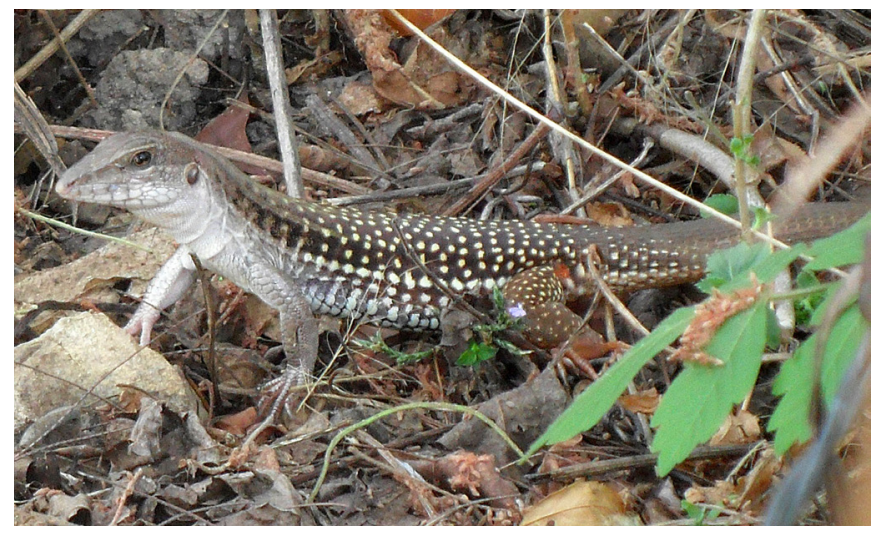

FiguRE 1. Individual of Aspidoscelis motaguae in life from Nicaragua (not collected).

Acknowledgments: We are grateful to Caio Antônio Figueiredo de Andrade for suggestions. Collecting and exportation permits were authorized by Carlos Mejia and Edilberto Duarte, MARENA (Ministry of Environment and Natural Resources), Managua, Nicaragua

\section{Literature Cited}

Duellman, W.E. and J. Wellman 1960. A sytematic study of the lizards of the deppei group (genus Cnemidophorus) in Mexico and Guatemala. Miscellaneous Publications University of Kansas Museum of Natural History 111: 1-81.

Holdridge, L.R. 1967. Life Zone Ecology. Revised Edition. San José: Tropical Science Center. 206 p.

Köhler, G. 2008. Reptiles of Central America. Second edition. Offenbach: Herpeton. 400 p.

Meyer, J.R. and L.D. Wilson 1973. A distributional checklist of the turtles, crocodilians, and lizards of Honduras. Contributions in Science Natural History Museum Los Angeles County 244: 1-39.

RECEIVED: July 2012

ACCEPTED: January 2013

PUBLISHED ONLINE: May 2013

EDITORIAL RESPONSIBILITY: Davi Pantoja 